\title{
Economic Analysis of Paddy Threshing Methods
}

\author{
P.H.S.N.Prasanna, L.H.P.Gunaratne and W.D.R.S.Withana *
}

\begin{abstract}
Post-harvest losses of paddy in Sri Lanka are as high as 15 percent of total production. Of this, about 24 percent of losses occur during the threshing and cleaning stage with tractor treading being the most common paddy threshing method. In order to overcome these deficiencies, recently small and combined threshers have been introduced. This study attempted to determine the efficiency of different paddy threshing methods, and to estimate the profitability of small and combined thresher ownership. The level of adaptability of mechanical threshing methods (i.e., tractor treading, small and combined threshers) and the factors that influence the adoption of paddy threshers were also investigated. Multi-stage random sampling was adopted to collect primary data based on a structured questionnaire from Pollonnaruwa district, one of the major rice growing areas in the country. Financial analysis was employed to find the profitability of thresher ownership. An empirical model was estimated to evaluate the efficiency of mechanical threshing methods based on the savings of labour and material. Logit model was fitted to identify the factors affecting thresher adoption. The study revealed that on average, small and combined threshers increase the net income per ha by Rs.6, 345 and Rs.9, 071 respectively, compared to tractor treading. Combined thresher ownership was found to be more profitable than small thresher ownership. The minimum economic operational area for tractor treading, small thresher and combined thresher were 41.78 halyr, 3.47 ha/yr and 20.97 ha/yr, respectively. Monthly income, wealth, cultivated extent and farming experiences were significantly related to the adoption of both small and combined threshers. Since replacing tractor treading by threshing machines reduces the post-harvest losses and increases the net income it is recommended that the availability of both types of threshers to be increased depending on farmer resource endowment.
\end{abstract}

*The authors are affiliated to the Department of Agricultural Economics and Business Management, Faculty of Agriculture, University of Peradeniya. 


\section{Background}

Post-harvest losses of paddy in Sri Lanka are estimated at 15 percent of the total production (Fernando and Palipane, 1983). Of this, 24 percent of losses occur during the threshing and cleaning stages (IPHT, 2002), which is equivalent to 110,520 metric tons of paddy or 1, 658 million rupees in 2003. This implies the need for technically as well as economically efficient threshing practices.

In Sri Lanka, mainly three types of mechanical paddy threshing methods (i.e. tractor treading, small thresher, combined thresher) are available. However, buffalo treading is still practiced in certain areas. Whether mechanical threshing can replace buffalo treading would not only be determined by technological feasibility but also by economic factors.

The selection of an appropriate threshing method depends on a number of other factors. For example, in the major rice growing areas like Pollonnaruwa, where most of the farmers depend on major irrigation, farming activities coincide with a severe labour shortage, especially during the harvesting season. If farmers leave matured paddy in the field, the grain losses will be accelerated due to shattering and rainfall. Therefore, efficient threshing practices are necessary to replace high labour requirements in the harvesting season.

In tractor treading, which is the most common paddy threshing method, grains are buried, splitted and internally cracked leading to head rice losses, which ultimately decrease profit margins to the farmers. Therefore, the best alternative threshing method for farmers should be based on labour saving, time saving and loss reduction. The private costs and benefits of thresher ownership determine the financial viability of thresher ownership.

With this background, the objectives of this study are to determine the adaptability of mechanical paddy threshing methods by comparing small threshers and combined threshers with tractor treading in terms of economic suitability and efficiency, and to financially analyze paddy thresher ownership. Moreover, socioeconomic factors and communication behavior that influence the adoption of threshing machines are also evaluated.

\section{Theoretical Framework}

The necessary theoretical framework for this analysis is set as follows. First, the concepts of estimating labour saving and product saving models are discussed. These are supplemented by plotting economic critical curves to identify 
the economic area to operate each thresher. Then cost-benefit analysis is used to identify the best threshing practice from the financial perspective, which is followed by fitting binary choice model to identify factors affecting adoption of threshing machines.

\section{a) Model for Economic Analysis of the Adaptability of Paddy Threshing Methods}

Following Meidui and Young (2002) the economic effectiveness can be quantified using two components namely, labour cost savings effects $\left(\mathrm{S}_{1}\right)$ and benefits from reducing losses $\left(\mathrm{S}_{2}\right)$.

\section{Labour Cost Savings Effect $\left(S_{1}\right)$}

The labour cost savings in mechanical threshing can be expressed as (Meidui and Young, 2002):

(1)

$$
S_{1}=\left(a_{1}-a_{2}\right) L W-b_{1} W-c_{1}
$$

Where

$S_{1}=$ Value of labour saved from mechanical threshing compared to buffalo treading (in rupees)

$L=$ Wage rate (in rupees/day)

$W=$ Area operate in a year by a mechanical threshing device (in ha)

$a_{1}, a_{2}=$ Man days/unit area for buffalo treading and mechanical threshing respectively $b_{1}=$ Variable costs of operation for mechanical threshing (rupees /unit area)

$c_{1}=$ Annual depreciation of mechanical threshing device (rupees /yr)

\section{Benefits from Reduced Losses $\left(S_{2}\right)$}

Similarly, the benefit from reduction of the grain losses is expressed as:

$S_{2}=\left(p_{1}-p_{2}\right) I W$

Where

$$
\begin{aligned}
& I=\text { Grain price( Rs. } / \mathrm{kg} \text { ) } \\
& W \quad=\text { Area operated in a year } \\
& P_{1}, p_{2}=\text { Grain losses per unit } \\
& \text { area for buffalo } \\
& \text { treading and } \\
& \text { mechanical threshing, } \\
& \text { respectively }
\end{aligned}
$$

\section{Comprehensive Benefits (S)}

The comprehensive benefits ( $\mathrm{S}$ ) will be then be the sum of $S_{1}$ and $S_{2}$.

(3)

$$
S=\left(a_{1}-a_{2}\right) L W-b_{1} W-c_{1}+\left(p_{1}-p_{2}\right) I W
$$

If $S>0$, adoption of mechanical threshing is worthwhile. The break even point gives the critical equation of the economic effect as:

(4)

$$
c_{1}=\left(a_{1}-a_{2}\right) L W-b_{1} W+\left(p_{1}-p_{2}\right) I W
$$




\section{b)Cost-Benefit Analysis}

In financial analysis, the benefits and costs realized over time are discounted to compare net return in present values. The environment cost is not considered since it is not our prime interest.

Net Present Value (NPV) is the present value of the cash flow stream i.e. the NPV of benefits less the NPV of costs (Gittinger,1982).

$$
N P V=\sum_{t=1}^{n} \frac{B_{t}-C_{t}}{(1+i)^{t}}
$$

where,

$$
\begin{aligned}
& \mathrm{B}_{\mathrm{t}}=\text { Benefits in each year } \\
& \mathrm{C}_{\mathrm{t}}=\text { Cost in each year } \\
& \mathrm{t}=\text { Time in years } 1 \ldots \mathrm{n} \\
& \mathrm{i}=\text { discount rate }
\end{aligned}
$$

Benefit-Cost Ratio (BCR) is computed on the basis of discounting the benefits and costs streams to their present values.

$$
B C R=\frac{\sum_{t=1}^{n} \frac{B_{t}}{(1+i)^{t}}}{\sum_{t=1}^{n} \frac{C_{t}}{(1+i)^{t}}}
$$

\section{c)Identification of Factors Affecting Adoption of Threshing Machine}

As indicated ealier, it is hypothesised that mechanical threshing, especially small and combined thrshing, are superior to existing practices, i.e., tractor and buffalo treading. In the previous two sections on the theoritical framework, the labour and grain savings, as well as net present values are computed to justify the adoption. Once that is done, then the factors influencing adoption need to be identified.

According to Rogers and Shoemaker (1971), the rate of adoption of new technology depends on socioeconomic characteristics, personal factors and communication behaviour. The socio economic charachteristics includes such as age, years of education, literacy, social status, social mobility, size of the farm, commercial orientation, credit availability, sprciality in operation while personal factors include empathy, dogmatism, abstraction ability, rationality, intelligence, attitude towards education and science, fatalistism, level of achievement motivation, aspiration for education, occupation. Social participation, social system, cosmopolitism, change agent contact, exposure to mass media, knowledge of innovation and opinion leadership belong to commecial related variables. Since the decision to adopt (i.e.,thresher ownership) is a dichotomous choice, a logit model can be used to identify the factors affecting the adoption of threshing devices, which can be expressed as, 
$\operatorname{Ln}\left(\mathrm{P}_{\mathrm{i}} / 1-\mathrm{P}_{\mathrm{i}}\right)=\mathrm{f}$ ( socio economic, farm-specific, and communication variables)

Where, $\mathrm{P}_{\mathrm{i}}=$ Probability of adoption.

Socio-economic variables include age of the farmer, monthly income, education, experience, and wealth of the farmer, while farm-specific variables include land extent and water availability. Contact with the extension worker, and social participation belong to the communication variable.

\section{Empirical Work}

\section{Collection of Data}

The study was conducted in the Pollonnaruwa district which is one of the major rice growing areas in the country. The district contributes 10.6 percent of the total harvested extent and 12.4 percent of total production in Sri lanka (Central Bank Annual Report, 2003). Most of the farmers in the district are full- time farmers and labour scarcity is quite common in the cultivating and harvesting seasons.

The study involved collecting and using both primary as well as secondary data. An interview schedule was developed to gather information from farmers who were threshing machine owners and non- owners. The key informants such as Agriculture Instructors, Grama Niladaris etc. were contacted to supplement the information.

In primary data collection, a multi-stage sampling method was adopted. From each of the eight Agrarian Service Centres (ASCs) in the district, one Agriculture Instructor's (AI) division was randomly selected, at the first stage. Discussion with the key informants such as officials of the Department of Agriculture and executives of the private firms revealed that there is no heterogenity of user pattern of threshers within the district.Therefore, at the second stage, nine farmers were randomly selected from each AI division chosen at the first stage in such a way that three farmers were from thresher non-owners, three farmers were from small thresher owners and three farmers were from combined thresher owners, thus making a total of seventy two respondents in the sample. The sampling scheme is depicted in figure 1 .

\section{Measurements}

The following variables were collected for all four types of paddy threshing methods, i.e., small thresher (AgrimecTH-2T which has a market share of 48 percent among the small threshers) with two-wheel tractor, combined thresher (CIC combined thresher which has a market share of 73 percent among 


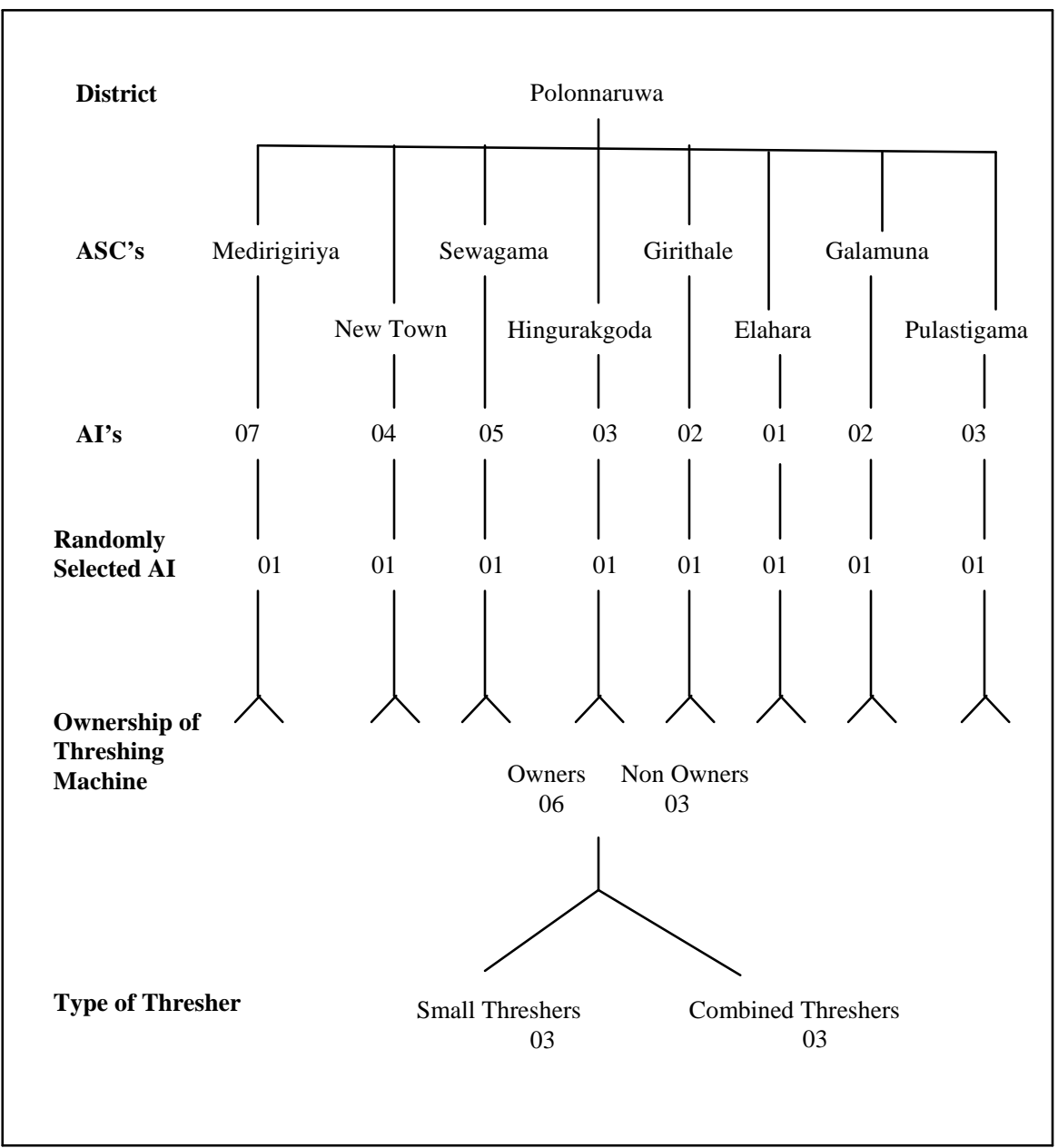

Figure 1: Sampling scheme

the combined threshers) with fourwheel tractor, tractor treading and buffalo treading. The following information were first obtained for each of the threshing methods.

- Amount of paddy acreage covered per day

- Cost of labour for threshing per unit area
- Initial cost of purchasing the machines(except buffalo treading)

- Rate of depreciation

- Operational and maintenance expenditure of different threshing devices

- Paddy losses in threshing per unit area 
In addition, the other relevant costs such as the initial expenditure on buying two-wheel tractors etc, were also collected.The questionaire included the socio-economic as well as farm-specific variables such as age, education, farm size, water availability, and contact with extension agent etc.

\section{Data Analysis}

Based on the models specified in the previous sections, the empirical models for labour savings and decrease in losses were estimated.The grain prices and wage rate were taken as Rs.15.00/kg and Rs.300.00/day, respectively. The nessecery graphs were obtained as:

\section{Case - 1}

The Farmer is More Interested in Labour Savings.

Three critical curves for mechanical threshing operations are tractor treading, small thresher and combined thresher can be consructed using unit area /yr (W) in $\mathrm{Y}$ axis and wage rate $(\mathrm{L})$ in $\mathrm{X}$ axis.Then the necessary economic operating area for every type of mechanical threshing method was determined.

\section{Case - 2}

\section{The Farmer is More Concerned With the Loss Reduction.}

Three critical curves for mechanical threshing operations were obtained as unit area/yr (W) in $\mathrm{Y}$ axis and grain price (I) in $\mathrm{X}$ axis. Then the necessary economic operating area for every type of mechanical threshing method was obtained.

The cost-benefit analysis in financial perspective was also computed. A sensitivity analysis was carried out to assess the stability of the project subject to fuel price changes. The following assumptions were made in the analysis:

- $\quad$ Fixed costs occur at the begining of the year.

- $\quad$ Costs and benefits occur at the end of each year.

- Economic life span for small thresher, combined thresher, 2 wheel tractor and 4 wheel tractor is equal to $20 \mathrm{yrs}$.

- $\quad$ Threshing days per year is 60 days and working hours per day is 8 hours.

- $\quad$ Fuel price is Rs.42.30 and wage rate is Rs.300.00/day.

- Machinery rent for tractor treading, small thresher and combined thresher are Rs.900.00/acre, 
Rs. $1,300.00 /$ acre

Rs.1800.00/acre.

The logit model was fitted to identify the factors responsible for adoption of threshing technology. The variables considered were age of the operator (years), monthly income (Rs), wealth (Rs), cultivated extent (ac), type of ownership (own/tenure: dummy), farming experience (yrs), contact with extension agent (no. of visits/month) and social participation.

\section{Results and Discussion}

\section{Economic Analysis on Adaptability of Paddy Threshing Methods}

Based on the methodology discussed in the previous section, different paddy threshing methods were evaluated.

Table 1 provides the mean values of the variables used for the analysis. The labour requirement is extremely low with combined threshing followed by small threshing. Moreover, grain losses are substantially low with combined threshing. Also, unit cost of threshing per unit area by these four different methods revealed that the cost is minimum with combined threshing. However, these values obtained from the field survey were slightly different from the recorded values shown in the table 2 .

Values of table 1 were used to estimate the equation (4). The economic benefits were computed and the economic benefit equations of tractor treading, small thresher and combined thresher are presented in table 3 .

\section{Labour Saving Effect}

The economically critical equations for labour savings show the relationship between indices $\mathrm{W}$ (Area/yr) and L (wage rate) as:

(5)

$$
W^{(1)}=\frac{78000}{(5.06 L-762.49)}
$$

$$
\begin{aligned}
& W^{(2)}=\frac{14772}{(6.56 L-245.23)} \\
& W^{(7)}=\frac{126500}{(8.12 L+5.55)}
\end{aligned}
$$

The superscripts 1, 2 and 3 stand for tractors, small threshers and combined threshers respectively.

The economically critical curves were obtained for the equations (6) to (7) (figure 2). The critical curves indicate that, for example, if wage rate is Rs.300/day, the necessary economic operational area for tractor treading, small thresher and combined thresher should be higher than $41.78 \mathrm{ha} / \mathrm{yr}$ (103.24 ac/yr), 3.47 $\mathrm{ha} / \mathrm{yr}(8.57 \mathrm{ac} / \mathrm{yr})$, and $20.97 \mathrm{ha} / \mathrm{yr}$ (51.81 ac/yr), respectively. 
Table 1: Means of variables of four threshing methods

\begin{tabular}{lcccc}
\hline \multicolumn{1}{c}{ Items } & $\begin{array}{c}\text { Tractor } \\
\text { Treading }\end{array}$ & $\begin{array}{c}\text { Small } \\
\text { Threshing }\end{array}$ & $\begin{array}{c}\text { Combined } \\
\text { Threshing }\end{array}$ & $\begin{array}{c}\text { Buffalo } \\
\text { Treading }\end{array}$ \\
\hline $\begin{array}{l}\text { Labour cost } \\
\text { (man }\end{array}$ & 9.74 & 6.03 & 2.17 & 22.24 \\
$\begin{array}{l}\text { days/ha) } \\
\text { Price of a } \\
\text { machine }\end{array}$ & $780,000.00$ & $147,720.00$ & $1,265,000.00$ & - \\
$\begin{array}{l}\text { (Rs.) } \\
\begin{array}{l}\text { Annual } \\
\text { depreciation }\end{array}\end{array}$ & $78,000.00$ & $14,772.00$ & $126,500.00$ & - \\
$\begin{array}{l}\text { (Rs.) } \\
\begin{array}{l}\text { Variable cost } \\
\text { (Rs./ha) }\end{array}\end{array}$ & $1,289.86$ & 909.91 & $1,616.03$ & - \\
$\begin{array}{l}\text { Fuel cost } \\
\text { Repair \& } \\
\text { maintenance }\end{array}$ & 288.00 & 221.00 & 275.00 & \\
$\begin{array}{l}\text { Grain losses } \\
\text { (kg/ha) }\end{array}$ & 345.94 & 286.64 & 197.68 & 306.40 \\
\hline
\end{tabular}

Table 2: Grain losses from different paddy threshing methods

\begin{tabular}{|c|c|}
\hline Type of paddy threshing & Head grain losses $\%$ \\
\hline 1. Buffalo treading & 6.2 \\
\hline 2. Tractor treading & 7.0 \\
\hline 3. Small thresher & 5.8 \\
\hline 4. Combined thresher & 4.0 \\
\hline
\end{tabular}

Sources: Fernando and Palipane, (1983)

\section{Loss Reduction Effect}

The economic critical equations for loss reduction effect give the relationship between indices W (Area/yr) and I (grain price) as:

(8)

$$
W^{(1)}=\frac{78000}{(995.51-16 I)}
$$


Table 3: Comprehensive benefits equations for mechanical threshing methods

\begin{tabular}{ll}
\hline \multicolumn{1}{c}{ Machine } & \multicolumn{1}{c}{ Comprehensive Benefit Equation } \\
\hline Tractor treading & $\mathrm{S}^{(1)}=5.06 \mathrm{LW}-522.49 \mathrm{~W}-16 \mathrm{IW}-78000$ \\
Small thresher & $\mathrm{S}^{(2)}=6.56 \mathrm{LW}-365.23 \mathrm{~W}+8 \mathrm{IW}-14772$ \\
Combined thresher & $\mathrm{S}^{(3)}=8.12 \mathrm{LW}-654.45 \mathrm{~W}+16 \mathrm{IW}-126500$
\end{tabular}

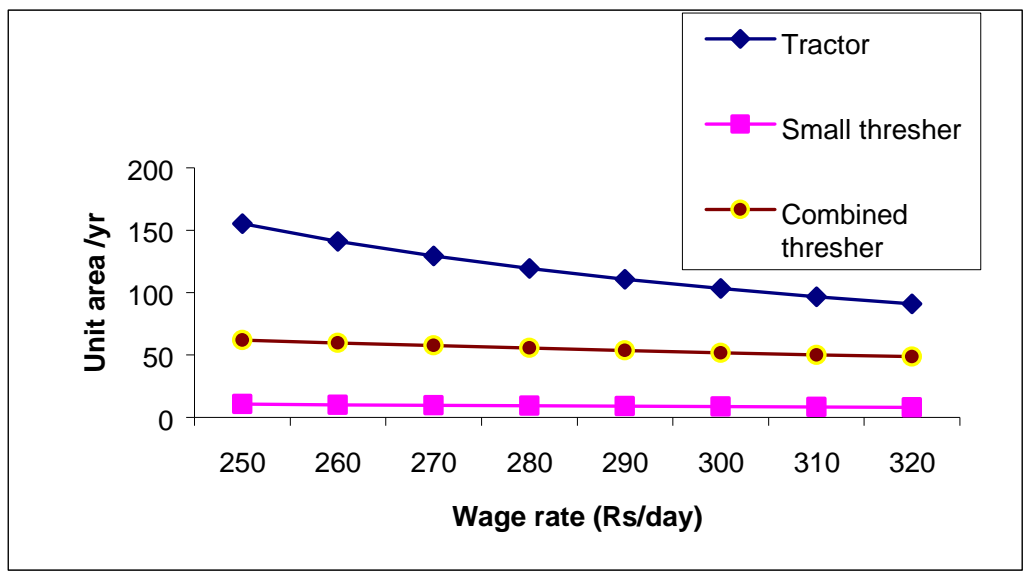

Figure 2: Economic critical curves emphasizing labour savings effect

(9)

$W^{(2)}=\frac{14772}{(1602.77+8 I)}$

$$
W^{(3)}=\frac{126500}{(1781.55+44 I)}
$$

As figure 3 displays, three economic critical curves result from the equations (8) to (10). These curves in figure 3 indicate that for example, if grain price was Rs.15.00/kg, the necessary economic operational area for tractor treading, small thresher and combined thresher should be $41.78 \mathrm{ha} / \mathrm{yr}(103.24 \mathrm{ac} / \mathrm{yr})$, $3.47 \mathrm{ha} / \mathrm{yr}(8.57 \mathrm{ac} / \mathrm{yr})$, and 20.97 ha/yr (51.81 ac/yr), respectively.

\section{a) Private Costs and Benefits for} Paddy Thresher Users

\section{Time Saving by Thresher Usage}

The survey results revealed that, when farmers used paddy threshers, they were able to save more time. This is more prominent with the combined threshers. Table 4 shows the average time spent on the different threshing practices for threshing and winnowing. 


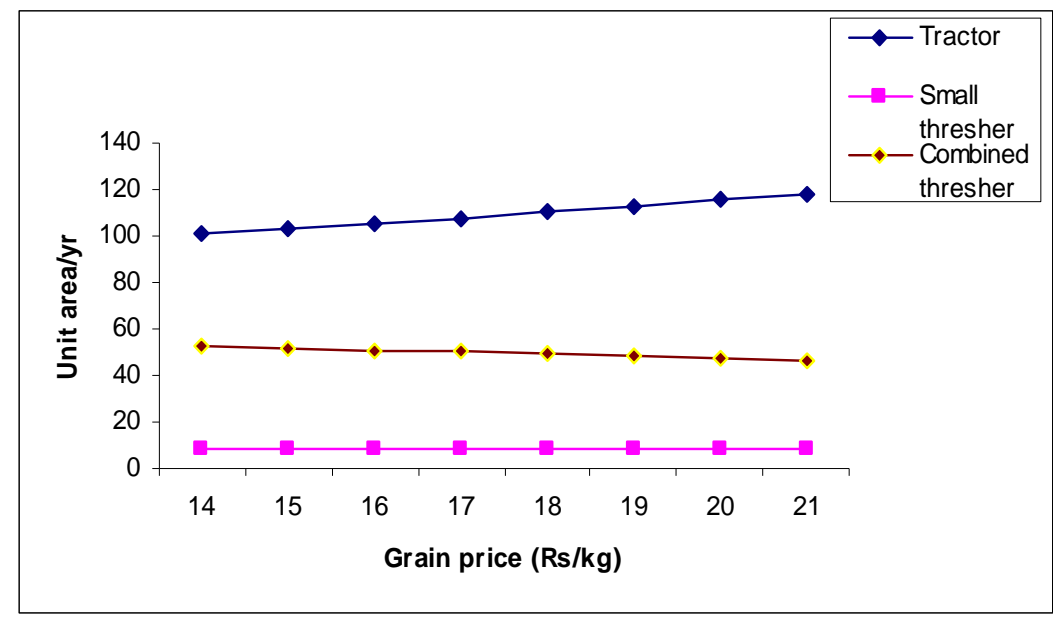

Figure 3: Economic critical curves when paying attention to loss reduction effect

Net Cost Savings Due to Paddy Thresher Usage

Cost savings by thresher usage leads to improved profitability in paddy cultivation. The mean net cost savings to farmers by switching from tractor treading to small threshers or combined threshers were Rs.454.66/ha (Rs.184.00/ac) and Rs.1756.88/ha (Rs.711.00/ac) respectively (Table 5).

\section{Additional Income to Farmers Due to Paddy Thresher Usage}

When farmers use mechanical threshers, (either small thresher or combined thresher instead of tractor treading) they can receive an additional Rs $1.00 / \mathrm{kg}$ due to stoneless, high quality paddy grains in addition to the reduction of head grain losses. Therefore, with the adoption of a small thresher or a combined thresher, farmers can increase the profit margin on average by Rs.6,345.53/ha (Rs.2,568.00/ac) or Rs.9,071.04/ ha (Rs.3671.00/ac) respectively (Table 6).

\section{b) Private Cost and Benefit for Paddy Thresher Owner}

According to the guidelines given in the methodology section, the study considered only the direct costs and benefits. Table 7 presents the revealed NPV, BCR, and IRR at $6 \%$, $8 \%, 10 \%, 15 \%$ and $20 \%$ discount rates. This shows that both small threshers and combined threshers provide positive net present values at all discount rates considered, compared to tractor treading. 
Table 4: Time spending for tractor treading threshing

\begin{tabular}{lccc}
\hline \multirow{2}{*}{ Activities } & \multicolumn{3}{c}{ Mean value of time spending (hr/ha) } \\
\cline { 2 - 4 } & Tractor treading & Small thresher & Combined thresher \\
\hline Threshing & 11.12 & 9.27 & 2.47 \\
Winnowing & 3.09 & 3.09 & 0 \\
Total & 14.21 & 12.36 & 2.47 \\
& & & \\
\hline
\end{tabular}

Table 5: Net cost savings by different threshing machines

\begin{tabular}{|c|c|c|c|c|c|}
\hline \multirow{3}{*}{ Cost Items } & \multicolumn{5}{|c|}{ Mean values (Rs/ha) } \\
\hline & \multicolumn{3}{|c|}{ Cost of paddy threshing } & \multicolumn{2}{|c|}{$\begin{array}{l}\text { Net cost saving } \\
\text { compared to tractor } \\
\text { treading }\end{array}$} \\
\hline & $\begin{array}{l}\text { Tractor } \\
\text { treading }\end{array}$ & $\begin{array}{c}\text { Small } \\
\text { thresher }\end{array}$ & $\begin{array}{l}\text { Combined } \\
\text { thresher }\end{array}$ & $\begin{array}{c}\text { Small } \\
\text { thresher }\end{array}$ & $\begin{array}{c}\text { Combined } \\
\text { thresher }\end{array}$ \\
\hline \multicolumn{6}{|l|}{$\begin{array}{l}\text { 1. Labour } \\
\text { cost }\end{array}$} \\
\hline Threshing & $3,407.51$ & $2,110.23$ & $1,482.60$ & $1,297.28$ & $1,924.91$ \\
\hline Winnowing & 943.92 & 798.13 & 0 & 145.79 & 943.92 \\
\hline \multicolumn{6}{|l|}{$\begin{array}{l}\text { 2. Machine } \\
\text { rent }\end{array}$} \\
\hline Threshing & $2,223.90$ & $3,212.30$ & 4200.70 & -988.40 & $-1,976.80$ \\
\hline Winnowing & 864.85 & 864.85 & 0 & 0 & 864.85 \\
\hline Total & $7,440.18$ & $6,985.51$ & $5,683.30$ & 454.67 & $1,756.88$ \\
\hline
\end{tabular}

Table 6: Additional income due to paddy thresher usage

\begin{tabular}{lrr}
\hline \multicolumn{1}{c}{ Mean values } & Small Thresher & Combined Thresher \\
\hline Net cost savings (Rs/ha) & 454.66 & $1,756.88$ \\
Value of loss reduction (Rs/ha) & 948.86 & $2,372.16$ \\
$\begin{array}{l}\text { Additional monitory gain due } \\
\text { to high price (Rs/ha) }\end{array}$ & $4,942.00$ & $4,942.00$ \\
\hline Total additional income (Rs/ha) & $6,345.52$ & $9,071.04$ \\
\hline
\end{tabular}

This provides the economic rationale threshers, combined thresher for using threshing machines over provides the highest value for NPV treading. Of the two types of and BCR at all discount rates. 
Therefore, disregarding the purchasing power of the farmer, adoption of the combined thresher appears to be economically worthwhile.

At the $20 \%$ discount rate, only the combined thresher had a positive NPV (table 7). This indicates that the project viability is not very stable when discount rate increases. With possible changes in fuel prices, table 8 shows that at a $10 \%$ fuel price increase, NPV and BCR values increase for small threshers as fuel expenditure is lower than that of tractor treading. These three indicators did not drastically change with the combined thresher.

\section{Factors Affecting Thresher Adoption}

It is of paramount importance to get an insight into the adoption process after economically analyzing the threshing practices. As described in the methodology section, a logit model was fitted to identify the variables that influence the adoption of each of the threshing machines. No serious multicolinearity problem was found among the independent variables.

Results of the analysis indicated that the independent variables such as age, land ownership, contact with extension agent and social participation were not significantly related to small thresher ownership. Variables such as monthly income, wealth, cultivated extent and farming experience were found to be significantly related to small thresher ownership at 0.05 level (Table 9).

A similar logit model was run to identify the variables for adoption of a combined thresher and it was found that the same variables influence adoption (Table 10).

Table 7: Financial NPV and BCR for small paddy thresher and combined paddy thresher

\begin{tabular}{ccccc}
\hline \multirow{2}{*}{$\begin{array}{c}\text { Discount } \\
\text { rate }\end{array}$} & \multicolumn{2}{c}{ Small thresher } & \multicolumn{2}{c}{ Combined thresher } \\
\cline { 2 - 5 } & NPV & BCR & NPV & BCR \\
\hline $6 \%$ & 125,552 & 1.026 & $2,895,588$ & 1.278 \\
$8 \%$ & 89,807 & 1.021 & $2,327,408$ & 1.257 \\
$10 \%$ & 62,243 & 1.017 & $1,884,522$ & 1.236 \\
$15 \%$ & 16,092 & 1.006 & $1,132,309$ & 1.184 \\
$20 \%$ & $-10,641$ & 0.995 & 681,933 & 1.137 \\
\hline
\end{tabular}


Table 8: Financial NPV, BCR, IRR for small paddy thresher and combined paddy thresher at $10 \%$ fuel price increase

\begin{tabular}{crrrr}
\hline \multirow{2}{*}{$\begin{array}{c}\text { Discount } \\
\text { rate }\end{array}$} & \multicolumn{2}{c}{ Small thresher } & \multicolumn{2}{c}{ Combined thresher } \\
\cline { 2 - 5 } & NPV (Rs.) & BCR (Rs.) & NPV (Rs.) & BCR (Rs.) \\
\hline $6 \%$ & 225,496 & 1.046 & $2,871,287$ & 1.272 \\
$8 \%$ & 165,104 & 1.039 & $2,306,606$ & 1.251 \\
$10 \%$ & 126,372 & 1.034 & $1,866,480$ & 1.230 \\
$15 \%$ & 61,054 & 1.022 & $1,119,033$ & 1.180 \\
$20 \%$ & 22,573 & 1.011 & 671,613 & 1.133 \\
\hline
\end{tabular}

Table 9: Results of the logit analysis for small thresher ownership

\begin{tabular}{lcc}
\hline \multicolumn{1}{c}{ Independent variables } & Estimated coefficient & t-Ratio \\
\hline Age (yrs) & 0.11056 & 1.1031 \\
Monthly income (Rs.) & 0.43366 & $1.7993^{*}$ \\
Wealth (Rs.) & 0.60890 & $2.19169^{*}$ \\
Cultivated extent (ac) & 0.55869 & $2.0092^{*}$ \\
Landownership (dummy, & 1.32550 & 0.81611 \\
own =1, tenure = 0) & & \\
Farming experience (yrs) & 0.13893 & $1.6274^{*}$ \\
Extension agent contact & -1.2645 & -0.88204 \\
Social participation & 3.7618 & 1.4521 \\
Constant & -16.5640 & -1.2572 \\
\hline
\end{tabular}

* Significant at 0.05

- $\quad$ Maddala $\mathrm{R}^{2}=0.56787$

- Likelihood ratio test $=40.2735$ with 10 degree of freedom

Table 10: Results of the logit analysis for combined thresher ownership

\begin{tabular}{lcc}
\hline \multicolumn{1}{c}{ Independent variables } & $\begin{array}{c}\text { Estimated } \\
\text { coefficient }\end{array}$ & T-Ratio \\
\hline Age(yrs) & 0.12814 & 1.1836 \\
Monthly income(Rs.) & 0.33661 & $1.8342^{*}$ \\
Wealth(Rs.) & 0.50890 & $1.79169^{*}$ \\
Cultivated extent(ac) & 0.34121 & $1.6593^{*}$ \\
Land ownership(dummy, & -1.9512 & -0.8678 \\
own =1, tenure =0) & 0.50057 & $1.62024^{*}$ \\
Farming experience(yrs) & -2.6768 & -0.73502 \\
Extension agent contact & 2.1740 & 0.66204 \\
Social participation & -21.6910 & -1.21660 \\
Constant & & \\
\hline
\end{tabular}


* Significant at 0.05

- Maddala $\mathrm{R}^{2}=0.65024$

- Likelihood ratio test $=50.4246$ with 10 degree of freedom

When compared these two results related to adoption (table 9 and 10), farming experiences have a higher effects on adoption of combined thresher compared to small thresher. However, the other three significant variables, monthly income, wealth and cultivated extend were more influenced on small thresher adoption compared to that of combined thresher.

\section{Conclusions and Recommendations}

This study attempted to economically analyse various paddy threshing devices, namely tractor treading, small threshing, and combined threshing. In order to accomplish this, labour savings and loss reduction models were estimated first. Then using the conventional cost-benefit analysis, the usage of different threshing practices was evaluated. The factors affecting their adoption were then found. According to the findings, when switching from tractor treading to thresher usage, a farmer can obtain mainly three types of benefits. i.e., time saving, net cost saving and additional income increase. Average time saved by small threshers and combined threshers were estimated as $1.85 \mathrm{hr} / \mathrm{ha}$ $(0.75 \mathrm{hr} / \mathrm{ac})$ and $11.74 \mathrm{hr} / \mathrm{ha}$ (4.75hr/ac), respectively. Such saved time could be used for better farm management, increased leisure activities or some other income generating activities. Mean cost saved by small threshers and combined threshers were Rs.454.66/ha (Rs.184.00/ac), and Rs.1756.88/ha (Rs.711.00/ac), respectively. Average additional income increase of small threshers and combined threshers were Rs.6345.52/ha (Rs.2,568.00/ac) and Rs.9071.04/ha (Rs.3,671.00/ac), respectively.

Thresher ownership is more profitable compared to tractor ownership for paddy threshing. Ownership of a combined thresher is more profitable than the ownership of a small thresher. Furthermore, financial viability of a combined thresher was not drastically changed with fuel price fluctuations. However, small thresher viability was sensitive to fuel price fluctuations.

It was estimated that, at the wage rate Rs.300.00/day, the necessary economic operational area for tractor treading, small thresher and combined thresher should be higher than 41.78ha/yr (103.24ac/yr), $3.47 \mathrm{ha} / \mathrm{yr}(8.57 \mathrm{ac} / \mathrm{yr})$, and $20.97 \mathrm{ha} / \mathrm{yr}$ (51.81ac/yr), respectively. Therefore, tractor treading and combined thresher usage are adaptable for regions where paddy cultivation is 
more extensive, while small thresher usage is appropriate for small to medium farms.

Furthermore, some of the variables selected to measure socioeconomic conditions and communication conditions were not found to be related to the adoption of both small and combined threshers. These were age, land ownership, extension agent contact and social participation. However, monthly income, wealth, cultivated extent and farming experience were found to be significant factors explaining adoption.

Given the high post-harvest losses, the study found that the promotion of threshing machines make a significant contribution to the nation's rice production as well as to the profitability of rice farming. This could be achieved by increasing the availability of threshing machines during the harvesting season by providing financial support to paddy farmers together with a dissemination programmeme.

The authors gratefully acknowledge the support given by Mr.Chandra Dharmasena (General ManagerBusiness development) and $M r$. Piyananda Dissanayaka (General Manager-Agriculture machinery) at CIC Agribusinesses, in conducting the study.

\section{References}

Central Bank of Sri Lanka. (2003). Annual Report, Colombo: Central Bank of Sri Lanka.

Fernando, M.D. and Palipane, K.B. (1983). A Comparative Study on Buffalo, Tractor and Mechanical Threshing in Sri Lanka. A Technical Report, Rice Processing Research and Development Centre. Anuradhapura.

Gittinger, J.P. (1982). Economic Analysis of Agricultural Projects, London: The John Hopkins, University Press.

Meidui D, and Young, $\mathrm{H}$. (2002).Technical and Economic Analysis on Adaptability of Typical Grain DryingPpatterns in South China. AMA. 33(2): 47-50

Rogers, Everett M. and F.F. Shoemaker. (1971). In Communication of Innovations. New York: The Free Press Publishers.

Technical Report for Paddy Postharvest Losses, (2002).Institute of Postharvest Technology, Anuradapura. 